\title{
Effective hydraulic conductivity and its relationship with the other attributes of Cerrado soils
}

\author{
Edwaldo D. Bocuti ${ }^{1}$, Ricardo S. S. Amorim ${ }^{2}$, Luis A. Di L. Di Raimo ${ }^{1}$, Wellington de A. Magalhães ${ }^{1}$ \& \\ Emílio C. de Azevedo ${ }^{3}$
}

${ }^{1}$ Universidade Federal de Mato Grosso/Programa de Pós-Graduação em Agricultura Tropical, Cuiabá, MT, Brasil. E-mail: ed.bocuti@hotmail.com (Corresponding author) - ORCID: 0000-0003-0700-1754; luis.diloreto@hotmail.com - ORCID: 0000-0003-0681-7647; wellingtonagro@gmail.com 0000-0001-8312-7055

${ }^{2}$ Universidade Federal de Viçosa/Centro de Ciências Agrárias/Departamento de Engenharia Agrícola, Viçosa, MG, Brasil. E-mail: rsamorim@ufv.br ORCID: 0000-0002-4570-1770

${ }^{3}$ Universidade Federal de Mato Grosso/Departamento de Solos e Engenharia Rural, Cuiabá, MT, Brasil. E-mail: emiliocarlosazevedo@gmail.com ORCID: 0000-0001-7789-723X

\begin{abstract}
The objective of this study was to determine the effective hydraulic conductivity of six areas located in the Cerrado region of Mato Grosso, Brazil, and to identify physical attributes of soils with potential for predicting effective hydraulic conductivity. The tests to determine the effective hydraulic conductivity were carried out in six areas, covering the textural classes sand, sandy loam and clay, and the following uses: pasture, Cerrado and agriculture. Particle size, sand fractionation, total carbon content, degree of clay flocculation, bulk density, macroporosity, microporosity, mean weight diameter, mean geometric diameter and aggregate stability index were determined. From the data, statistical analyses of contrasts were performed by the Kruskal - Wallis test, and simple Pearson's correlation coefficient was determined between variables. The average values of effective hydraulic conductivity for the pasture, agriculture and Cerrado areas were 95.73, 27.83 and $48.31 \mathrm{~mm} \mathrm{~h}^{-1}$, respectively. Higher value of effective hydraulic conductivity was observed in the Pasture area point 2 when compared to the Agriculture area point 2, because the amount of clay determined in Agriculture area was approximately 16 times greater than that of the area Pasture point 2, conditioning lower water infiltration in the soil profile of the area Agriculture point 2. Among the physical attributes analyzed, those with the highest potential for Ke prediction were: clay, silt, sand (coarse, medium and fine), total carbon and aggregate stability index.
\end{abstract}

Key words: simulated rainfall, soil loss, water infiltration rate

\section{Condutividade hidráulica efetiva e sua relação com os demais atributos dos solos do Cerrado}

RESUMO: Objetivou-se neste estudo determinar a condutividade hidráulica efetiva de seis áreas localizadas no Cerrado Mato-Grossense e identificar atributos físicos dos solos com potencial de predição da condutividade hidráulica efetiva. Os ensaios da condutividade hidráulica efetiva foram executados em seis áreas, contemplando solos de classes texturais areia, franco arenosa e argila e os seguintes usos: pastagem, Cerrado e agricultura. Foram determinadas a granulometria, fracionamento da areia, teor de carbono total, grau de floculação da argila, densidade do solo, macroporosidade, microporosidade, diâmetro médio ponderado, diâmetro médio geométrico e índice de estabilidade de agregados. A partir dos dados foram realizadas análises de contrastes pelo teste de Kruskal-Wallis e determinação do coeficiente de correlação de Pearson simples entre variáveis. Os valores médios de condutividade hidráulica efetiva para as áreas pastagem, agricultura e Cerrado foram, respectivamente, 95,73;27,83 e 48,31 $\mathrm{mm} \mathrm{h}^{-1}$. Maior valor de condutividade hidráulica efetiva foi observado na área Pastagem ponto 2 quando comparada à área Agricultura ponto 2, devido à quantidade de argila determinada na área agricultura ser aproximadamente 16 vezes maior que a da área pastagem, $o$ que condicionou a menor taxa de infiltração da água no perfil do solo da área agricultura ponto 2 . Dentre os atributos físico avaliados, aqueles que apresentaram maior potencial para predição da Ke, foram: argila, silte, areia (grossa, média e fina), carbono total e índice de estabilidade de agregados.

Palavras-chave: chuva simulada, perda de solo, taxa de infiltração da água 


\section{INTRODUCTION}

Increments in production costs and reduction in the productive capacity of agricultural areas are conditioned by soil loss (Dechen et al., 2015), which has water erosion as one of its main causes. In studies involving the quantification of soil losses by water erosion, hydraulic conductivity is a relevant hydrological attribute, as it expresses the dynamics of soil water movement.

According to Gonçalves \& Libardi (2013), hydraulic conductivity expresses the ease with which water moves in the soil. Therefore, it directly influences the volume of runoff, enhancing the capacity to transport particles and impacting the erosion process.

In addition, knowing the hydraulic conductivity of the soil enables the planning of actions aimed at conserving the environment, agricultural areas and water resources, minimizing losses of soil, water and solutes in unsaturated soils.

There are several methodologies for determining soil hydraulic conductivity, which can be carried out in the field or in the laboratory (Silva Junior et al., 2013). When determined in the field with the aid of a rainfall simulator, it is called effective soil hydraulic conductivity $\left(\mathrm{K}_{\mathrm{e}}\right)$, but this determination is laborious (Mubarak et al., 2010), requires time and generates high costs. In this context, it is necessary to find soil attributes that are predictors of $\mathrm{K}_{\mathrm{e}}$ for tropical soils and thus enable the generation of adequate mathematical models to estimate it.

The scarcity of values of $\mathrm{K}_{\mathrm{e}}$ and of properties with potential for its prediction has made it difficult to adapt functions to estimate this soil attribute, which makes it impossible to use erosion prediction tool for tropical edaphoclimatic conditions. Thus, the objective of this study was to obtain the $\mathrm{K}_{\mathrm{e}}$ of the soil of six areas in the Cerrado region of Mato Grosso, Brazil, and to identify physical and physical-hydraulic attributes of the soil with the potential for predicting $\mathrm{K}_{\mathrm{e}}$.

\section{Material ANd Methods}

The study was conducted in the municipalities of Campo Verde and Santo Antônio de Leverger, both in the state of Mato Grosso, Brazil. The tests for determining the effective hydraulic conductivity $\left(\mathrm{K}_{\mathrm{e}}\right)$ were performed in six areas (Table $1)$, contemplating soils with the textural classes sand, sandy loam and clay, and the following uses: pasture (Points 1 and 2 - Pp1 and Pp2), Cerrado (C) and agriculture (Points 1, 2 and 3 - Ap1, Ap2 and Ap3).

The study was conducted in three stages. The first stage consisted of the characterization of the physical and physicalhydraulic attributes of the soils of the areas where the field tests were performed; in the second stage, the tests were carried out to determine $\mathrm{K}_{\mathrm{e}}$; and in the third stage the correlation between $\mathrm{K}_{\mathrm{e}}$ and soil attributes was evaluated.

In the characterization stage, disturbed samples, undisturbed samples and soil clods were collected in each area, in four mini soil pits at $0-0.20 \mathrm{~m}$ depth, and used for the determination of particle size, sand fractionation, bulk density, total carbon content, degree of clay flocculation, macroporosity, microporosity, mean weight diameter, mean geometric diameter and aggregate stability index in four replicates (Table 2 ).

Analyses of particle size and degree of flocculation were performed using the pipette method (EMBRAPA, 2017). Sand fractions were obtained by dry sieving, following the scale of Soil Survey Staff (2017). Total carbon content was determined using the Total Carbon (TC) analyzer, N/C 3100 model, coupled to the device HT 1300 Solids Module.

Macroporosity and microporosity were determined based on the manual of soil analysis methods (EMBRAPA, 2017). Aggregate stability was evaluated using semi-preserved samples passed through a $4.00-\mathrm{mm}$-mesh sieve and retained on 2.00-mm-mesh sieve; to obtain the aggregates, these were subjected to wet sieving by the standard method of Yoder (EMBRAPA, 2017).

The mean weight diameter (MWD) and mean geometric diameter (MGD) of the aggregates were obtained by wet sieving, as respectively proposed by Van Bavel (1949) and Schaller \& Stockinger (1953).

Bulk density was determined by the volumetric cylinder method, based on the manual of soil analysis methods (EMBRAPA, 2017).

The tests for determining effective hydraulic conductivity followed the methodology proposed by the Agricultural Research Service of the United States Department of Agriculture (ARS/USDA) (Elliot et al., 1989), which consisted in conventionally tilling an area with dimensions of $10 \times 10 \mathrm{~m}$, by one plowing with a disc plow and two harrowings, at $0.20 \mathrm{~m}$ depth. In the recently tilled area, galvanized plates were used

Table 1. Characteristics of the pedological units studied

\begin{tabular}{|c|c|c|c|c|c|c|}
\hline $\operatorname{Mb}(7)$ & Area/points & Location & Veg (8) & $S(9)$ & A.I. (10) & Texture \\
\hline \multirow{2}{*}{ I } & Pp1(1) & $\begin{array}{l}15^{\circ} 48.527^{\prime} \mathrm{S} \\
55^{\circ} 20.052^{\prime} \mathrm{W}\end{array}$ & Pasture & $13.60 \%$ & Presence of gravel & Sandy \\
\hline & Pp2(2) & $\begin{array}{l}15^{\circ} 48.493^{\prime} \mathrm{S} \\
55^{\circ} 19.793^{\prime} \mathrm{W}\end{array}$ & Pasture & $3.70 \%$ & Absence of gravel & Sandy \\
\hline \multirow{2}{*}{$\|$} & Ap1(3) & $\begin{array}{r}15^{\circ} 44.484^{\prime} \mathrm{S} \\
55^{\circ} 21.797^{\prime} \mathrm{W}\end{array}$ & Fallow & $5.33 \%$ & Fallow for 5 years & Clayey \\
\hline & Ap2(4) & $\begin{array}{l}15^{\circ} 44.865^{\prime} \mathrm{S} \\
55^{\circ} 2.278^{\prime} \mathrm{W}\end{array}$ & Corn & $1.60 \%$ & Recently harvested corn & Clayey \\
\hline III & $C(5)$ & $\begin{array}{l}15^{\circ} 47.628^{\prime} \mathrm{S} \\
55^{\circ} 20.300^{\prime} \mathrm{W}\end{array}$ & Cerrado & $5.55 \%$ & Roots of native plants & Medium \\
\hline IV & Ap3(6) & $\begin{array}{l}15^{\circ} 50.600^{\prime} \mathrm{S} \\
55^{\circ} 20.400^{\prime} \mathrm{W}\end{array}$ & Corn & $6.70 \%$ & Recently harvested corn & Clayey \\
\hline
\end{tabular}

(1) Pasture point 1; (2) Pasture point 2; (3) Agriculture point 1; (4) Agriculture point 2; (5) Cerrado 1; (6) Agriculture 3; (7) Micro-basin; (8) Vegetation; (9) Local slope; (10) Additional information 
Table 2. Physical characterization of the soils where $\mathrm{K}_{\mathrm{e}}$ tests were performed

\begin{tabular}{|c|c|c|c|c|c|c|}
\hline \multirow[b]{2}{*}{ Atribute } & \multicolumn{6}{|c|}{ Areas } \\
\hline & $\begin{array}{l}\text { Pasture } \\
\text { point } 1\end{array}$ & $\begin{array}{c}\text { Pasture } \\
\text { point } 2\end{array}$ & $\begin{array}{l}\text { Agriculture } \\
\text { point } 1\end{array}$ & $\begin{array}{l}\text { Agriculture } \\
\text { point } 2\end{array}$ & Cerrado & $\begin{array}{c}\text { Agricultur } \\
\text { point } 3\end{array}$ \\
\hline & \multicolumn{6}{|c|}{$\mathrm{g} \mathrm{kg}^{-1}$} \\
\hline Clay & 30.80 & 31.80 & 519.70 & 521.10 & 135.30 & 572.10 \\
\hline Silt & 43.20 & 21.80 & 179.80 & 123.50 & 117.10 & 119.80 \\
\hline Sand & 925.80 & 946.30 & 300.40 & 355.30 & 747.60 & 308.10 \\
\hline Very coarse sand & 95.30 & 198.00 & 6.10 & 8.30 & 21.30 & 6.10 \\
\hline Coarse sand & 68.10 & 91.60 & 37.60 & 38.50 & 46.10 & 36.20 \\
\hline Sum of very coarse sand and coarse sand & 163.40 & 289.60 & 43.80 & 46.80 & 67.40 & 42.20 \\
\hline Medium sand & 162.90 & 251.60 & 90.10 & 96.10 & 160.30 & 89.90 \\
\hline Fine sand & 479.10 & 508.30 & 128.50 & 159.50 & 399.10 & 127.20 \\
\hline Very fine sand & 120.30 & 74.80 & 38.10 & 52.80 & 120.60 & 50.80 \\
\hline \multirow[t]{2}{*}{ Total carbon } & 0.56 & 0.40 & 33.80 & 29.40 & 14.40 & 36.90 \\
\hline & \multicolumn{6}{|c|}{$\mathrm{kg} \mathrm{dm}^{-3}$} \\
\hline \multirow[t]{2}{*}{ Bulk density } & 1.69 & 1.58 & 1.11 & 0.97 & 1.37 & 1.05 \\
\hline & \multicolumn{6}{|c|}{$\mathrm{mm}$} \\
\hline Mean geometric diameter & 1.22 & 1.63 & 2.21 & 1.85 & 2.76 & 2.10 \\
\hline \multirow[t]{2}{*}{ Mean weight diameter } & 1.76 & 2.19 & 2.56 & 2.48 & 2.89 & 2.54 \\
\hline & \multicolumn{6}{|c|}{$\%$} \\
\hline Aggregate stability index & 78.59 & 26.59 & 93.45 & 86.93 & 96.06 & 93.99 \\
\hline Degree of clay flocculation & 45.49 & 57.66 & 71.85 & 67.14 & 50.34 & 97.25 \\
\hline Macroporosity & 27.36 & 24.61 & 10.56 & 23.37 & 27.07 & 19.89 \\
\hline Microporosity & 12.87 & 18.93 & 46.34 & 38.34 & 24.44 & 40.56 \\
\hline
\end{tabular}

to delimit three experimental plots with dimensions of $0.70 \mathrm{x}$ $1.00 \mathrm{~m}$, with the largest dimension in the direction of greater slope of the area.

Each experimental plot was subjected to a continuous simulated rain with average precipitation intensity of approximately $65 \mathrm{~mm} \mathrm{~h}^{-1}$, except in the area of pasture, points 1 and 2 (Pp1 and $\mathrm{Pp} 2$ ), where the mean precipitation intensity was approximately $145 \mathrm{~mm} \mathrm{~h}^{-1}$. Adopting higher precipitation intensity in points $\mathrm{Pp} 1$ and $\mathrm{Pp} 2$ was necessary to enable the occurrence of surface runoff.

The rainfall simulator used had Veejet 80.100 nozzles at a pressure of $32.7 \mathrm{kPa}$. The desired precipitation intensity was previously set by adjusting the opening of the infiltrometer shutters. The uniformity of water distribution by the infiltrometer was expressed by the Christiansen's uniformity coefficient, which was equal to $85 \%$.

Soil water infiltration rate was calculated indirectly, based on the difference between the precipitation volume and the surface runoff volume, collected in the plots at each interval of $5 \mathrm{~min}$. Knowing that effective hydraulic conductivity assumes values close to that of the steady-state water infiltration rate, then equality between these attributes was adopted.

The $\mathrm{K}_{\mathrm{e}}$ values of the study areas were compared by contrasts between the different treatments using the Kruskal-Wallis test. This nonparametric test was used because the present study did not follow an experimental design. To identify soil physical attributes with potential for $\mathrm{K}_{\mathrm{e}}$ prediction, an analysis of correlation between $\mathrm{K}_{\mathrm{e}}$ and the other soil attributes was performed using simple Pearson's correlation coefficient.

\section{Results AND Discussion}

Figure 1 presents the soil water infiltration rate as a function of the time of simulated rainfall application, for the studied areas. Each point represents the average of three repetitions.
The tests to determine the effective hydraulic conductivity of the soil $\left(\mathrm{K}_{\mathrm{e}}\right)$ lasted on average 114, 118, 115, 98, 204 and 126 min per repetition, for the areas of Pasture point 1 (Pp1), Pasture point 2 (Pp2), Agriculture point 1 (Ap1), Agriculture point 2 (Ap2), Cerrado (C) and Agriculture point 3 (Ap3), respectively.

The longest duration of 204 min occurred in the Cerrado, where the roots of native plants removed in the conventional soil tillage formed preferential channels for water, which functioned as drains.

At the beginning of the test, the drains were slightly clogged by soil, but over time they were cleared by the water, making it difficult to establish a constant film of water, which compromised the stability of the runoff and, consequently, the end of $\mathrm{K}_{\mathrm{e}}$ test.

Applying higher precipitation intensity in Pp1 and Pp2 caused the soil water infiltration capacity to be achieved more quickly, which led to puddling followed by surface runoff in the initial 5 min of the test. Alves \& Cabeda (1999) also found a reduction in $\mathrm{T}_{\mathrm{p}}$ and $\mathrm{Es}_{0}$, in a Ultisol, when subjected to two precipitation intensities, and attributed it to the increase in precipitation intensity.

On the other hand, the higher precipitation intensity in Pp1 and Pp2 also generated an increase in the kinetic energy of the impact of raindrops on the soil, causing disaggregation and a new surface arrangement of particles, since the soil was extremely sandy, recently mechanized and with no vegetation cover.

Such arrangement may have compromised pore continuity at the beginning of the test, consequently reducing the time of puddling and surface runoff. Panachuki et al. (2011), in a study on water loss in agriculture, also verified influence of the impact of raindrops on the surface arrangement of soil particles.

At the beginning of the test for areas Pp1 and Pp2 it was possible to observe a sharp drop in soil water infiltration rate, 


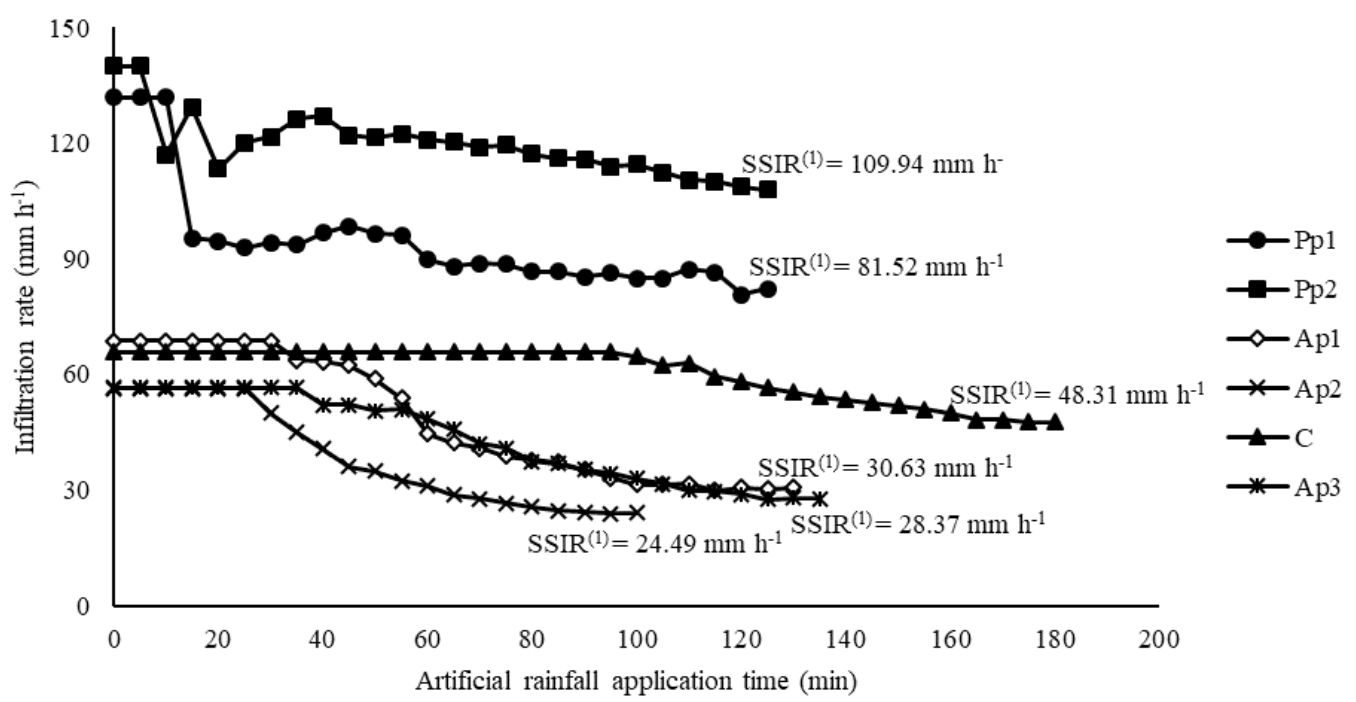

(1) Steady-state infiltration rate; Pasture point 1 (Pp1); Pasture point 2 (Pp2); Agriculture point 1 (Ap1); Agriculture point 2 (Ap2); Cerrado (C) and Agriculture point 3 (Ap3) Figure 1. Soil water infiltration rate as a function of the time of artificial rainfall application in six areas

followed by infiltration rates close to stabilization. This abrupt alternation of infiltration followed by stabilization occurred only in soils with high sand content.

The arrangement of sand particles and the maintenance of soil macroporosity enabled the establishment of continuous flow of water and, consequently, standardization in water infiltration rate.

However, it is important to emphasize that even after the decrease in infiltration, the soils of the areas Pp1 and Pp2 showed stable infiltration rates above $63.5 \mathrm{~mm} \mathrm{~h}^{-1}$ and were classified as of moderate permeability, based on the manual of Soil Survey Staff (2017).

According to the trend of soil water infiltration, the areas Ap1, Ap2 and Ap3 (Figure 1) tended to have lower water infiltration capacity, which can be explained by the clay content and microporosity of these soils, which were on average 519.70, 521.10 and $572.10 \mathrm{~g} \mathrm{~kg}^{-1}$ and 46.34, 38.34 and $40.56 \%$, respectively (Table 2 ).

The clay content and microporosity of the areas Ap1, Ap2 and Ap3 led to slower water percolation and increased the water retention capacity by the soil, resulting in lower steady-state infiltration rates and, consequently, lower values of $\mathrm{K}$. Klein \& Klein (2015), studying soil water retention and availability, claim that the clay fraction is among the factors that establish water retention. Thus, texture was more important than soil structure in the control of water infiltration, retention and percolation.

The Kruskal-Wallis test $(\mathrm{p} \leq 0.05)$ showed that there was a significant difference for $\mathrm{K}_{\mathrm{e}}$ only between the areas Ap2 and $\mathrm{Pp} 2$, and the highest value of effective hydraulic conductivity was observed in the area Pp2 (Table 3). The main difference between the attributes of the areas Ap2 and Pp2 is the clay and sand contents of the soils (Table 2).

The amount of clay determined in Ap2 was approximately 16 times higher than that of $\mathrm{Pp} 2$, which after conventional tillage of the soil resulted in the lowest infiltration and slower passage of water by the profile of Ap2 and also favored water retention and reduced the speed of displacement of the wetting front, reducing the effective hydraulic conductivity of the
Table 3. Effective hydraulic conductivity for different study areas

\begin{tabular}{|lc|}
\hline \multicolumn{1}{|c|}{ Areas } & $\begin{array}{c}\text { Effective hydraulic conductivity } \\
\left(\mathrm{mm} \mathrm{h}^{-1}\right)\end{array}$ \\
\hline Pasture point 1 (Pp1) & $81.52(15.8) \mathrm{ab}$ \\
Pasture point 2 (Pp2) & $109.94(19.34) \mathrm{a}$ \\
Agriculture point 1 (Ap1) & $30.63(6.76) \mathrm{ab}$ \\
Agriculture point 2 (Ap2) & $24.49(3.12) \mathrm{b}$ \\
Cerrado (C) & $48.31(13.41) \mathrm{ab}$ \\
Agriculture point 3 (Ap3) & $28.37(4.76) \mathrm{ab}$ \\
\hline Means followed by the same lowercase letter in the column do not differ by Kruskal-Wallis
\end{tabular}

test at $\mathrm{p} \leq 0.05$; Values between parentheses represent the standard deviation

soil. According to Stefanoski et al. (2013), soil management practices influence the structure, size and quantity of pores, which influences both water retention and hydraulic conductivity.

The contents of sand and the sum of the fractions very coarse sand (VCS) and coarse sand (CS) were respectively 946.30 and $289.60 \mathrm{~g} \mathrm{~kg}^{-1}$ for Pp2 and 355.35 and $46.80 \mathrm{~g} \mathrm{~kg}^{-1}$ for Ap2, that is, $\mathrm{Pp} 2$ had sand particles of coarser fractions compared to Ap2. Soils with coarser particle size tend to have pores of larger diameters, which thus enable greater infiltration, percolation and hydraulic conductivity of the soil.

These results corroborate those obtained by Bielschowsky et al. (2012), who studied the hydraulic conductivity of soils with different textures and found higher values in two Quartzipsamments, and the hydraulic conductivity was higher in the one with highest content of coarse sand (CS).

Compared to Pp2, the area Ap2 tended to have higher values of total carbon, mean geometric diameter, mean weight diameter and aggregate stability index (Table 2), characteristics that influence soil macroporosity and favor the increase in effective hydraulic conductivity. On the other hand, the area $\mathrm{Pp} 2$ had sand content of $946.30 \mathrm{~g} \mathrm{~kg}^{-1}$ and higher $\mathrm{K}_{\mathrm{e}}$, demonstrating again that, in recently tilled soils, the texture plays a decisive role in water percolation.

Based on the manual of Soil Survey Staff (2017), with regard to the effective hydraulic conductivity of the soils, the areas could be divided into two groups: the first one composed of Pp1 and Pp2, with $K_{e}$ values between 63.50 and $127.00 \mathrm{~mm} \mathrm{~h}^{-1}$, 
classifying $\mathrm{K}_{\mathrm{e}}$ as moderate; and the second one composed of Ap1, Ap2, C and Ap3, with $K_{e}$ values between 20 and $63.50 \mathrm{~mm}$ $\mathrm{h}^{-1}$, classifying $\mathrm{K}_{\mathrm{e}}$ as slow to moderate. This division is mainly due to the sand contents of the soils, because the first group is composed of sandy soils and the second is composed of clayey and medium-textured soils (Table 1 ).

The effective hydraulic conductivity was significantly correlated, $\mathrm{p} \leq 0.01$ by t-test, with all physical attributes of the soils of the study areas (Table 4).

The effective hydraulic conductivity showed a positive correlation with the sand content and sand fractions, indicating that soils with higher values of these attributes had higher capacity for water infiltration and percolation and, consequently, higher values of $\mathrm{K}_{\mathrm{e}}$. These results corroborate those found by Fiorin (2008), who stated that sandy soils, due to their higher macroporosity, have higher rates of infiltration and hydraulic conductivity.

The attributes clay and silt showed a negative correlation with the effective hydraulic conductivity, that is, the increase in the finer fractions of the soil led to reduction in $\mathrm{K}_{e}$. Clay and silt contributed to the increase in soil microporosity, intensifying the retention and decreasing the percolation of water in the profile. Alonso (2005) also found that the finer fractions of the soil form channels with smaller dimensions for the passage of water, reducing the hydraulic conductivity of the soil.

It is worth pointing out that the clay and silt fractions, when dispersed, cause partial interruption of soil pores, which compromises the flow of water, contributing to the reduction in $\mathrm{K}_{\mathrm{e}}$. This occurred because the finer fractions of the soil are more easily moved by the water flow and accommodated in the porous spaces, mainly because the soil has undergone conventional tillage before the start of $\mathrm{K}_{\mathrm{e}}$ tests.

Pedron et al. (2011) also found that the finest fractions of the soil, present in the surface horizon, can be translocated by the movement of water along the soil profile and deposited in macropores, hence leading to reduction and/or discontinuity of pores, thus decreasing permeability.

Rizzardi et al. (2014) attributed the decrease of hydraulic conductivity in soils with higher contents of fine particles to the migration of silt and clay from the mobilized layers to the site located immediately below the plowed layer.

Table 4. Correlation between effective hydraulic conductivity $\left(K_{e}\right)$ with the physical attributes of the studied soils

\begin{tabular}{|c|c|}
\hline Attribute & $\mathbf{R}^{2}$ \\
\hline Clay & $-0.88 * \star$ \\
\hline Silt & $-0.90^{* *}$ \\
\hline Sand & $0.92^{\star \star}$ \\
\hline Very coarse sand & $0.52^{* *}$ \\
\hline Coarse sand & $0.99 * *$ \\
\hline Sum of very coarse sand and coarse sand & $0.82^{* *}$ \\
\hline Medium sand & $0.95 * *$ \\
\hline Fine sand & $0.91 * *$ \\
\hline Very fine sand & $0.50 * *$ \\
\hline Total carbon & $-0.92^{* *}$ \\
\hline Mean geometric diameter & $-0.54^{* *}$ \\
\hline Mean weight diameter & $-0.62^{\star \star}$ \\
\hline Aggregate stability index & $-0.85^{\star \star}$ \\
\hline Degree of clay flocculation & $-0.59 * *$ \\
\hline Bulk density & $0.87 * *$ \\
\hline
\end{tabular}

** - Significant at $\mathrm{p} \leq 0.01$ by t-test
The degree of flocculation (DF) had a negative correlation with $\mathrm{K}_{e}$, that is, soils with lower percentages of flocculated clay had higher values of effective hydraulic conductivity. This can be explained by the peculiarity of the studied soils, as Pp1, Pp2 and $C$ had DF equal to $45.49,57.66$ and $50.34 \%$, respectively, but also showed clay contents of $30.80,31.80$ and $135.30 \mathrm{~g}$ $\mathrm{kg}^{-1}$, respectively, so even with lower percentages of DF they also had low levels of water-dispersible clays (WDC), which partially contributed to pore obstruction and compromised water infiltration, causing a reduction in $\mathrm{K}_{e}$.

According to Freitas (2011), WDC can migrate to depths that provide conditions for flocculation and thus obstruct the pores and alter the dynamics of water in the soil.

The effective hydraulic conductivity of the soil had a negative correlation with total carbon, that is, the accumulation of organic matter in the $0-20 \mathrm{~cm}$ layer contributed to the decrease in $\mathrm{K}_{\mathrm{e}}$. Two facts explained this situation; the first one is that soils with sand contents above $920 \mathrm{~g} \mathrm{~kg}^{-1}$, that is, sandy textural class, have low physical potential in protecting and accumulating organic matter, consequently having lower contents of total carbon, but higher values of $\mathrm{K}_{\mathrm{e}}$; and the second one is that the highest contents of organic matter intensified the capacity for water retention in the soil, causing a decrease in $\mathrm{K}_{\mathrm{e}}$.

Carvalho et al. (2007), studying an Oxisol, also found the tendency of hydraulic conductivity values to increase with depth, the inverse arrangement of the accumulation of carbon content in soil profiles.

Density was significantly and positively correlated with the effective hydraulic conductivity of the soil. This can be explained because the soil of the pasture area has average total porosity $\left(41.89 \mathrm{~g} \mathrm{~cm}^{-3}\right)$ composed mainly of macropores, while agricultural areas have average total porosity (59.69 g $\mathrm{cm}^{-3}$ ) mostly composed of micropores. Thus, in the pasture area, even with higher densities, the higher mean values of macroporosity $\left(25.98 \mathrm{~g} \mathrm{~cm}^{-3}\right.$ ) enabled a more pronounced percolation of water in the soil.

The mean geometric diameter (MGD), mean weight diameter (MWD) and aggregate stability index (ASI) were negatively correlated with the effective hydraulic conductivity of the soil, that is, it was observed that the better structured soils had lower $\mathrm{K}_{\mathrm{e}}$. However, these correlations are commonly positive, as stated by Gonçalves \& Libardi (2013).

Nonetheless, the negative correlations between $\mathrm{K}_{e}$ and the attributes related to soil aggregates, observed in the present study (Table 4), occurred due to the great variation in the contents of sand and clay between the pasture areas (Ap1 and Ap2) and the agriculture areas (Ap1, Ap2 and Ap3), because when the correlation of $\mathrm{K}_{\mathrm{e}}$ with the MGD, MWD and ASI only of the areas with medium texture $(C)$ and clayey texture (Ap1, Ap2 and Ap3), the $K_{e}$ tended to increase with the elevation of these attributes (Figure 2). Bocuti et al. (2019) also found that there was greater water percolation in better structured soils, i.e., with aggregates of larger diameter and more stable.

In this perspective, in order to obtain better correlations between $\mathrm{K}_{\mathrm{e}}$ and the soil attributes that express aggregate stability and dimension, it is initially important to group soils by textural class, so it is possible to obtain better correlations 

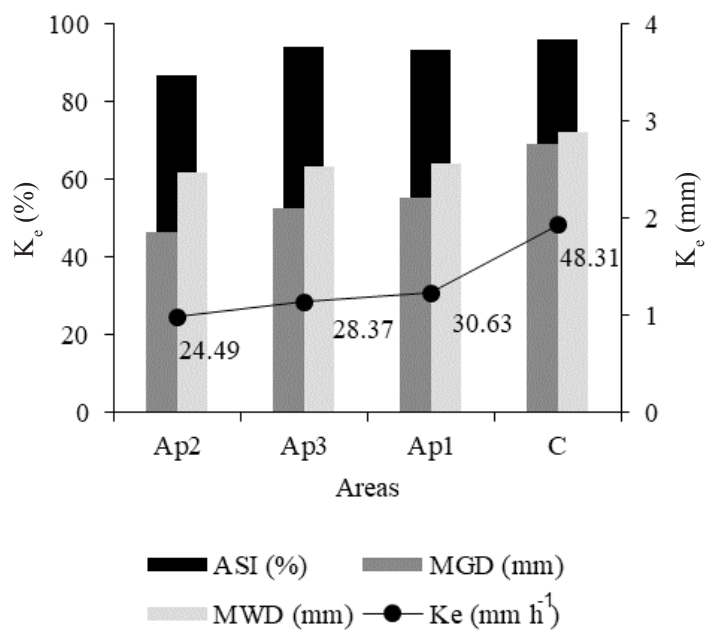

MGD - Mean geometric diameter; MWD - Mean weight diameter; ASI - Aggregate stability index; $\mathrm{K}_{\mathrm{e}}$ - Effective hydraulic conductivity

Figure 2. Relationship between effective hydraulic conductivity and the indices of evaluation of aggregate stability of mediumtextured and clayey soils

and, through these, propose mathematical models that estimate $\mathrm{K}_{\mathrm{e}}$ more accurately.

\section{Conclusions}

1. The effective hydraulic conductivity was higher in soils with sandy texture, and the values determined in the study areas ranged from 24.49 to $109.94 \mathrm{~mm} \mathrm{~h}^{-1}$, with highest value in the Pasture point 2 ( $\mathrm{Pp} 2)$.

2. The sand content and its different fractions showed a significant and positive correlation with the effective hydraulic conductivity of the soil, while negative correlations were found between $\mathrm{K}_{\mathrm{e}}$ and the attributes silt, clay, total carbon, mean geometric diameter, mean weight diameter, aggregate stability index and degree of flocculation.

\section{ACKNOWLedgments}

To Conselho Nacional de Desenvolvimento Científico e Tecnológico - CNPq (Proc. n 481990/2013-5) and Fundação de Amparo à Pesquisa do Estado de Mato Grosso - FAPEMAT (335908/2012) for funding the study and granting the scholarship. Both provided opportunity for our professional growth and permanence at the University.

\section{Literature Cited}

Alonso, T. P. Condutividade hidráulica de solos compactados em ensaios com permeâmetro de parede flexível. São Carlos: USP, 2005. 120p. Dissertação Mestrado

Alves, M. C.; Cabeda, M. S. V. Infiltração de água em um Podzolico Vermelho Escuro sob dois métodos de preparo, usando chuva simulada com duas intensidades. Revista Brasileira de Ciência do Solo, v.23, p.753-761, 1999. https://doi.org/10.1590/S0100-06831999000400001

Bielschowsky, C.; Barbosa, A. C.; Lima, L. A.; Silva Júnior, G. C. Determinação da condutividade hidráulica saturada de campo em solos com diferentes texturas utilizando o método do permeâmetro IAC. Caderno de Estudos Geoambientais, v.3, p.44-55, 2012.
Bocuti, E. D.; Amorim, R. S. S.; Santos, T. G.; Raimo, L. A. di L.; Pereira, H. G. Erodibilidade entressulcos e sua relação com atributos de solos do cerrado. Revista Ciências Agrárias de Portugal, v.42, p.68-78, 2019.

Carvalho, L. A.; Libardi, P. L.; Rocha, G. C.; Cruz, A. C. R. Caracterização hidráulica de um Latossolo vermelho associada à caracterização pedológica do perfil. Ciência Rural, v.37, p.10081013, 2007. https://doi.org/10.1590/S0103-84782007000400014

Dechen, S. C. F.; Telles, T. S.; Guimaraes, M. F.; Maria, I. C. Perdas e custos associados à erosão hídrica em função de taxas de cobertura do solo. Bragantia, v.74, p.224-233, 2015. https://doi. org/10.1590/1678-4499.0363

Elliot, W. J.; Liebenow, A. M.; Laflen, J. M.; Kohl, K. D. A Compendium of soil erodibility data from WEPP cropland soil field erodibility experiments 1987 and 1988. Report. 3. West Lafayette: USDAARS, 1989.

EMBRAPA - Empresa Brasileira de Pesquisa Agropecuária. Manual de métodos de análises de solos. 3.ed. Rio de Janeiro: Embrapa Solos, 2017. 574p.

Fiorin, T. T. Estimativa da infiltração de água no solo a partir de pedofunções. Santa Maria: UFSM, 2008. 97p. Tese Doutorado

Freitas, R. C. A. Argila dispersa em água determinada por agitação rápida, lenta e ultrassom. Viçosa: UFV, 2011. 50p. Dissertação Mestrado

Gonçalves, A. D. M. A.; Libardi, P. L. Análise da determinação da condutividade hidráulica no solo pelo método do perfil instantâneo. Revista Brasileira de Ciência do Solo, v.37, p.11741184, 2013. https://doi.org/10.1590/S0100-06832013000500007

Klein, C.; Klein, V. A. Estratégias para potencializar a retenção e disponibilidade de água no solo. Revista Eletrônica em Gestão, Educação e Tecnologia Ambiental, v.19, p.21-29, 2015.

Mubarak, I.; Angulo-Jarmillo, R.; Mailhol, J. C.; Ruelle, P.; Khaledian, M.; Vauclin, M. Spatial analysis of soil surface hydraulic properties: Is infiltration method dependent? Agricultural Water Management, v.97, p.1517-1526, 2010. https://doi.org/10.1016/j. agwat.2010.05.005

Panachuki, E.; Bertol, I.; Alves Sobrinho, T.; Oliveira, P. T. S.; Rodrigues, D. B. B. Perdas de solo e de água e infiltração de água em Latossolo Vermelho sob sistemas de manejo. Revista Brasileira de Ciência do Solo, v.35, p.1777-1786, 2011. https:// doi.org/10.1590/S0100-06832011000500032

Pedron, F. A.; Fink, J. R.; Rodrigues, M. F.; Azevedo, A. C. Condutividade e retenção de água em Neossolos e saprolitos derivados de Arenito. Revista Brasileira de Ciência Solo, v. 35, p.1253-1262, 2011.

Rizzardi, A. S.; Righes, A. A.; Kemerich, P. D. C.; Silva, R. F.; Santos, S. A.; Borba, W. F. Atributos físicos e fluxo de água em solos da bacia hidrográfica do rio Vacacaí-Mirim - RS. Revista Monografias Ambientais, v.13, p.3690-3701, 2014.

Schaller, F. W.; Stockinger, K. R. A. Comparison of five methods for expressing aggregation data. Soil Science Society of America Proceedings, v. 17, p.310-313, 1953. https://doi.org/10.2136/ sssaj1953.03615995001700040002x

Silva Junior, J. J.; Colombo, A.; Silva, E. L.; Scalco, M. S. Determinação da condutividade hidráulica do solo utilizando o problema inverso do software hydrus-1d. Revista Agro@mbiente On-line, v.7, p.242251, 2013. https://doi.org/10.18227/1982-8470ragro.v7i3.1128

Soil Survey Staff. Soil Survey manual: Soil conservation service. Washington: USDA, 2017. 639p. Handbook 18 
Stefanoski, D. C.; Santos, G. G.; Marchão, R. L.; Petter, F. A.; Pacheco, L. P. Uso e manejo do solo e seus impactos sobre a qualidade física. Revista Brasileira de Engenharia Agricultura e Ambiental, v.17, p.1301-1309, 2013. https://doi.org/10.1590/S1415-43662013001200008
Van Bavel, C.J.M. Mean weight-diameter of soil aggregates as a statistical index of aggregation. Soil Science Society of America Journal, v.14, p.20-23, 1949. https://doi.org/10.2136/ sssaj1950.036159950014000C0005x 